\title{
Development of a Biosensor Based on Myrtle (Myrtus communis L.) Tissue Homogenate for Voltammetric Determination of Epinephrine
}

\author{
Voltametrik Epinefrin Tayinine Yönelik Hambeles (Myrtus \\ communis L.) Doku Homojenatı \\ Temelli Biyosensör Sistemi Geliştirilmesi
}

\author{
Research Article
}

\section{Adnan Ayna1*, Erol Akyilmaz²}

'Department of Chemistry, Faculty of Sciences and Arts, Bingol University, Bingol, Turkey. ${ }^{2}$ Department of Biochemistry, Faculty of Science, Ege University, Bornova, izmir, Turkey.

\section{A B S TR AC T}

\begin{abstract}
A plant tissue based biosensor was proposed for voltammetric determination of epinephrine (EP) in A pharmaceutical samples. The tissue homogenate was immobilized by crosslinking with glutaraldehyde on the glassy carbon. The polyphenol oxidase enzymes present in fibers of a myrtle tree fruits maintained high bioactivity on this biomaterial, catalyzing the oxidation of epinephrine to epinephrinequinone. Under optimize working conditions, the biosensor showed a linear response in the range of 10-100 $\mu \mathrm{M}$. The limit of detection (LOD) was calculated as $3.2 \times 10^{-6} \mathrm{~mol} \mathrm{~L}^{-1}(3.2 \mu \mathrm{M}$ ) (3 per slope). The reproducibility, expressed as the relative standard deviation (RSD) for seven consecutive determinations of $5.0 \times 10^{-5} \mathrm{~mol} \mathrm{~L}^{-1}$ EP was $4.6 \%$. The biosensor retained $70 \%$ activity after 11 days of storage in a phosphate buffer at $4{ }^{\circ} \mathrm{C}$. The applicability of this biosensor was demonstrated with the analysis of real samples and a good correlation was obtained between results acquired by the biosensor and those measured by spectrophotometric method. Such favorable results obtained with the myrtle tissue homogenate based biosensor, joined with the simplicity and low-cost of its preparation turns these procedures very attractive for EP quantification in pharmaceutical products.
\end{abstract}

\section{Key Words}

Epinephrine, biosensor, tissue homogenate, voltammetric determination.

\section{öz}

\begin{abstract}
— armasotik numunelerde epinefrinin (EP) voltametrik tayini için bitki dokusuna dayalı yeni bir biyosensor - geliştirildi. Doku homojenatı, camsı karbon üzerinde glutaraldehit ile çapraz bağlanarak immobilize edildi. Yaban mersininde (Myrtus communis L.) bulunan polifenol oksidaz enzimleri, epinefrinin epinefrinkinon'a oksidasyonunu katalize eder. Optimize edilmiş çeşitli operasyonel parametreler altında, biyosensor 10-

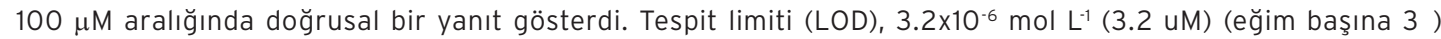
olarak hesaplandı. $5.0 \times 10^{-5} \mathrm{~mol} \mathrm{~L}^{-1}$ EP'nin yedi ardışık ölçüm sonucu için göreli standart sapma (RSD) \% 4.6 olarak hesaplandı. Biyosensor, $4^{\circ} \mathrm{C}$ 'de bir fosfat tamponunda 11 gün depolandıktan sonra \%70 etkinliğini muhafaza ettiği için çok iyi stabiliteye sahiptir. Bu biyosensorun uygulanabilirliği, gerçek numunelerin analizi ile gösterildi ve biyosensor tarafından elde edilen sonuçlar ile spektrofotometrik yöntemle ölçülen sonuçlar arasında iyi bir korelasyon elde edildi. Myrtle doku homojenatına dayalı biyosensor ile elde edilen bu olumlu sonuçlar, hazırlanmasının basitliği ve düşük maliyetiyle birleşti ve bu prosedürleri farmasotik ürünlerdeki EP kantifikasyonu için cazip hale getirildi.
\end{abstract}

\section{Anahtar Kelimeler}

Epinefrin, biyosensor, doku homojenat, voltametrik tayin.

Article History: Received: Mar 1, 2018; Revised: Mar 28, 2018; Accepted: Jul 6, 2018; Available Online: Oct 4, 2018.

DOI: $10.15671 /$ HJBC.2018.240

Correspondence to: A. Ayna, Department of Chemistry, Faculty of Sciences and Arts, Bingol University, Bingol, Turkey. 


\section{INTRODUCTION}

D evelopment of biosensors using plant tissues have gained great interest because of their availability, low cost and high level of enzymatic activity owing to the inherent protection by the natural environment [1]. Furthermore, the usage of plant tissue offers advantages such as no need tedious and time-consuming sample preparation steps which then turns into simple, sensitive, and fast alternative determination methods for a wide range of applications including pharmaceutical analysis [2].

Epinephrine (EP), or adrenaline is a member of catecholamine family and one of the key neurotransmitters in mammalian central nervous systems $[3,4]$. The alterations in the concentration of EP may cause many diseases including smooth muscles contraction, blood pressure, glycogenolysis and lipolysis [5]. Great e orts have been made to improve analytical methods for the determination of EP concentration in various samples due to its importance for nerve physiology, pharmacological research and the life sciences.

A wide variety of methods have been proposed to detect EP concentration some of which are spectrophotometric $[6,7]$, chromatographic $[8,9]$, flow injection analysis [10], fluorimetric [11,12], capillary electrophoresis [13] and voltammetric methods [14]. However, some of these methods are expensive or complicated and in need of extraction or derivatization steps as well. Biosensors developed using plant tissue materials in combination with transducers offer an alternative as compared to biosensors based on isolated enzymes as well as others analytical techniques in detection of catecholamines [15]. These biosensors have some advantages, such as low cost, simplicity of construction and needless of a co-factor for enzyme regeneration [16]. Herein, a tissue homogenate-based biosensor is proposed for voltammetric detection of EP in pharmaceutical samples. Plant tissues from fruits of a common myrtle (Myrtus communis L.) tree in southern Turkey, with a high content of polyphenol oxidase enzymes (PPO), were used. The homogenate of this fruits is immobilized onto the glassy carbon electrode via gelatin, and cross-linked by glutaraldehyde. The high content of PPO in the fibers of a myrtle tree fruits maintained high bioactivity on this biomaterial, catalyzing the oxidation of EP to epinephrinequinone as a primary product. The aim of the work described in this paper is to propose a biosensor for the determination of EP concentration in pharmaceutical samples. In order to obtain the best biosensor response, optimization of bioactive layer and working conditions along with its characterization studies are required. The electrochemical behavior of EP on the modified electrode was explored by means of cyclic voltammetry (CV). The results were compared with standard method that uses UV spectrophotometry.

\section{MATERIALS and METHODS}

\section{Apparatus}

Experiments were carried out using Palm Sense (Netherland) potentiostat, a three electrode system - a CHI 104 model glassy-carbon-workingelectrode (GCE), a CHI 111 model $\mathrm{Ag} / \mathrm{AgCl}$ saturated reference electrode and a $\mathrm{CHI} 115$ model platinum wire auxiliary electrode.

\section{Reagents}

All the reagents used in this study were of analytical grade. Buffer solutions were prepared in bidistilled water. Skin-calf-gelatin (225 bloom), glutaraldehyde (25\%), potassium phosphate monobasic, sodium hydroxide, hydrochloric acid, alumina, sodium acetate and sodium periodate were purchased from Sigma Chemical Co. (USA). Benzoquinone was purchased from Fluka. Myrtle was harvested in Hatay-Turkey and was used in the experiments. Adrenaline ampules were purchased from Biofarma Drug Company (Turkey) and Galen Drug Company (Turkey). All solutions used in experiments were freshly prepared just before their use.

\section{Preparation of Bioactive Layer}

First, myrtle tissue (200 mg) was homogenized in the phosphate buffer $(300 \mu \mathrm{l})$ by using a manual glass homogenizer. Then, the homogenate (200 $\mu \mathrm{l})$ and gelatin $(5 \mathrm{mg}$ ) were mixed and incubated at $38^{\circ} \mathrm{C}$ for 5 minutes to dissolve the gelatin. After that, $50 \mu$ of mixture was carefully spread 


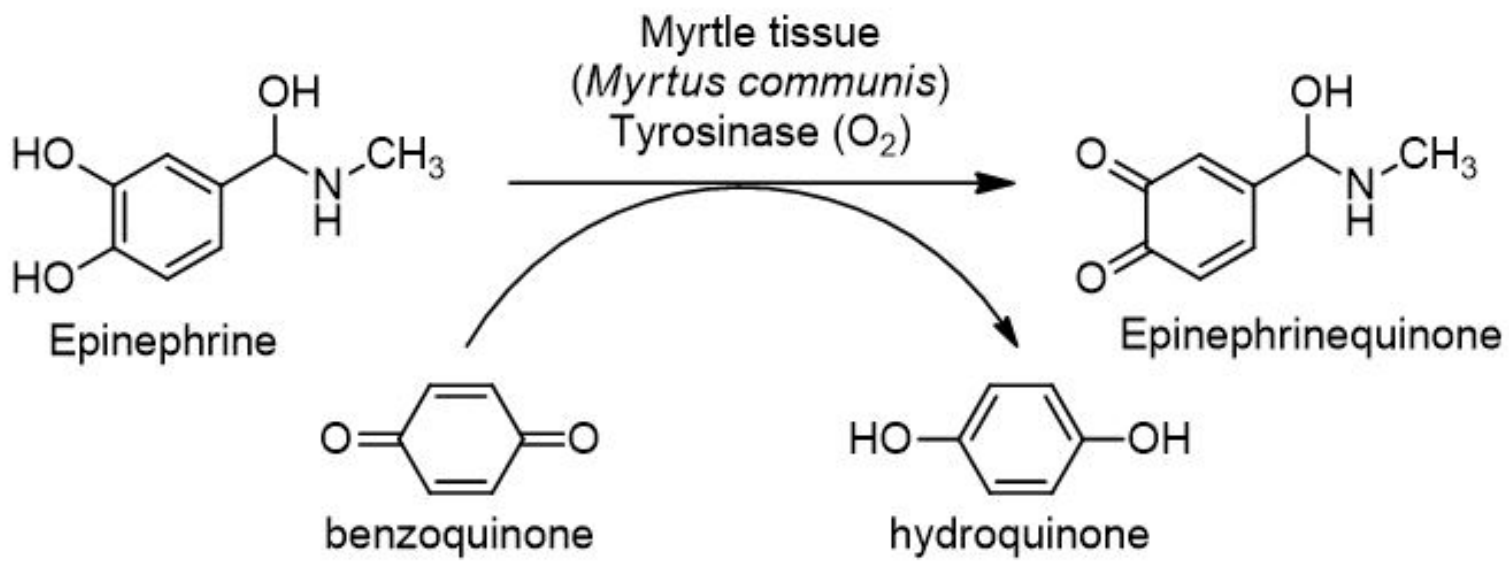

Scheme 1. The working mechanism of Myrtle tissue homogenate based electrochemical biosensing system for voltammetric analysis of epinephrine.

over the glassy carbon electrode (with a surface area of $0.23 \mathrm{~cm}^{2}$ ) and allowed to dry at $4^{\circ} \mathrm{C}$ for 30 minutes. At the final step for the cross-linking, the electrode was immersed in $2.5 \%$ glutaraldehyde for 5 minutes.

\section{Principle of the Measurements}

Myrtle tissue including polyphenol oxidase can oxidize EP to epinephrinequinone by using dissolved oxygen $[17,18]$. Since the dissolution of oxygen in water is limited, using a mediator like $p$-benzoquinone overcomes the dissolution problem of oxygen. When EP is oxidized to epinephrinequinone, $\mathrm{p}$-benzoquinone is reduced to hydroquinone (scheme 1). Hence, the principle of measurements is based on monitoring the increase in the current at the reduction potential of $p$-benzoquinone (at $-0.05 \mathrm{~V}$ ) by using the cyclic voltammetric method. Cyclic voltammograms were taken at a potential range between $-0.3 \&$ $0.3 \mathrm{~V}$ (scan rate $25 \mathrm{mV} / \mathrm{s}$ ) and increases in the biosensor responses and polyphenol oxidase activity were monitored. During all measurements, $1 \mathrm{mM}$ p-benzoquinone which was used as a mediator was prepared in phosphate buffer (50 $\mathrm{mM}, \mathrm{pH}: 7$ ).

\section{RESULTS and DISCUSSION}

\section{Optimization of Bioactive Layer}

To detect the effect of amount of the tissue homogenate on the biosensor response, different amount of the homogenates were used in the biosensor preparation. For this purpose, three different amount of tissue homogenates were selected (100 mg, $200 \mathrm{mg}$ and $400 \mathrm{mg}$ ). Results obtained from the experiments are given in Figure 1a. According to the results, the highest biosensor responses and the most suitable calibration curves were obtained when $200 \mathrm{mg}$ tissue was used in the biosensor preparation (The thickness of modified electrode was calculated to be 0.4 $\mathrm{cm}$ when $200 \mathrm{mg}$ tissue was used). Low current values resulted when a $100 \mathrm{mg}$ tissue sample was used because of the insufficient amount of tissue. When 400 mg sample was used, response of the biosensor was expected to be higher. However, due to the dense unit volume of the tissue, the substrate diffusion problem resulted in extension of biosensor response time. Herein, a 4-minute biosensor response was measured. If the time is extended for the $400 \mathrm{mg}$ sample a better biosensor response could be acquired.

After detecting the effects of amount of tissue homogenate on the biosensor response, the effects of other parameters such as amount of gelatin and percentage of glutaraldehyde on the biosensor response were investigated respectively. For the investigation the effect of gelatin, the amount of tissue homogenate and glutaraldehyde were kept constant as $200 \mathrm{mg}$ and $2.5 \%$, whereas, different amounts of gelatin (5 mg, $10 \mathrm{mg}$ and $20 \mathrm{mg}$ ), were used in the biosensor construction. Results obtained from the experiments are given in Figure 1b. According to the results, the highest biosensor responses and the most suitable calibration curves were 
obtained when $10 \mathrm{mg}$ gelatin was used in the biosensor preparation. When higher and lower amounts of gelatin were used in the biosensor construction, decreases in the biosensor response were observed. We speculate that when the amount of gelatin was $5 \mathrm{mg}$, the diffusion layer becomes thin; therefore, the tissue might not be attached effectively which results in tissue loss from the bioactive layer of the biosensor caused decrease in biosensor response. On the other hand, when $20 \mathrm{mg}$ of gelatin was used, the diffusion layer thickens, it causes difficulty for the substrate diffusion from the reaction medium to the electrode, which then turned into decreased biosensor response.

After the optimal amounts of the tissue homogenate and gelatin were determined as $200 \mathrm{mg}$ and $10 \mathrm{mg}$, respectively, During the investigation of the effect of glutaraldehyde concentration on the biosensor response, the amount of tissue homogenate and gelatin were kept constant as $200 \mathrm{mg}$ and $10 \mathrm{mg}$ where each of the newly prepared tissue biosensors were treated with $1.25 \%, 2.5 \%$ and $5 \%$ glutaraldehyde t. The results obtained from the experiments are given in Figure 1c. When 1.25 and 5.0\% glutaraldehyde were used, a slight decrease was observed on the biosensor response due to inadequate gelatin-gelatin cross-linkings that caused deformation of the bioactive layer which would lead to decrease in biosensor response. When the cyclic voltammograms and the current values were evaluated, the best glutaraldehyde concentration was obtained $2.5 \%(\mathrm{w} / \mathrm{w})$.

\section{Optimization of the Working Conditions}

The effect of concentration of the benzoquinone on the biosensor response was examined using different concentration of the benzoquinone in the biosensor preparation. Three different concentration of benzoquinone were selected ( $0.5 \mathrm{mM}, 1 \mathrm{mM}$ and $2 \mathrm{mM}$ benzoquinone) for that purpose. With the result of the experiments the best current values and the voltammograms were obtained with $1 \mathrm{mM}$ benzoquinone (Figure 1d) Optimization of $\mathrm{pH}$ is one of the key parameters for biosensor studies. The performance of the a)

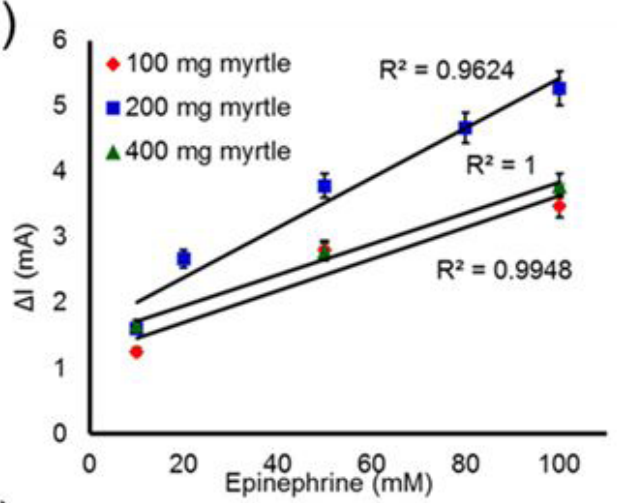

c)

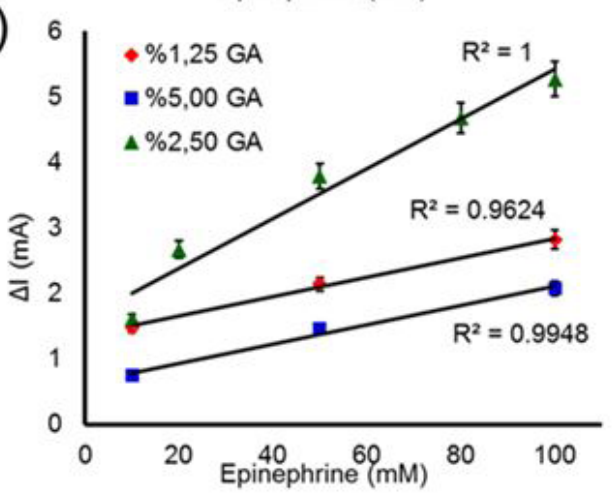

b)

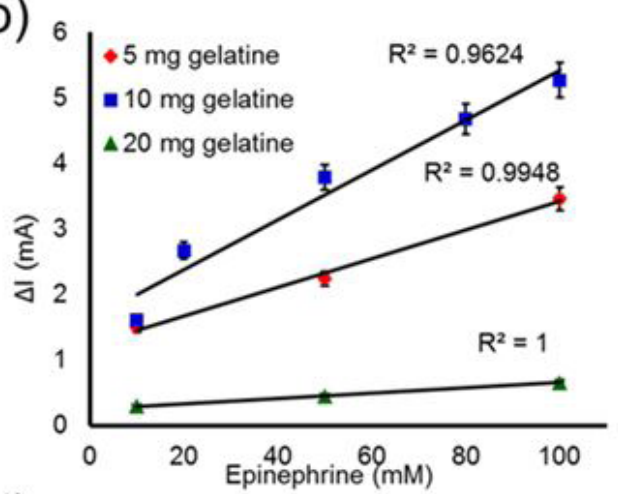

d) 12

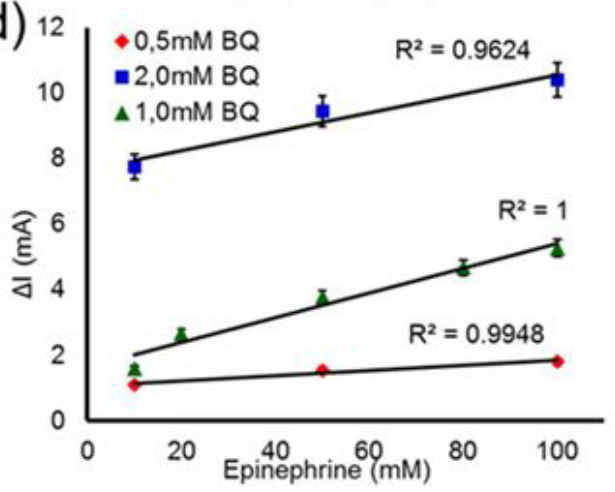

Figure 1. Optimization of a) myrtle tissue, b) gelatin, c) glutaraldehyde, d) benzoquinone amounts on biosensor response. 
a)

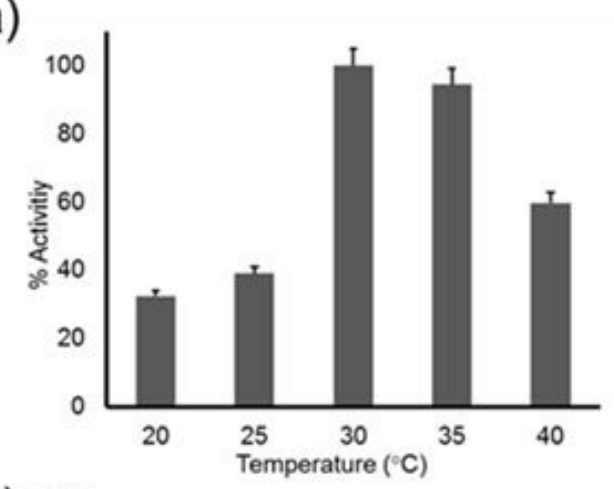

c) 8

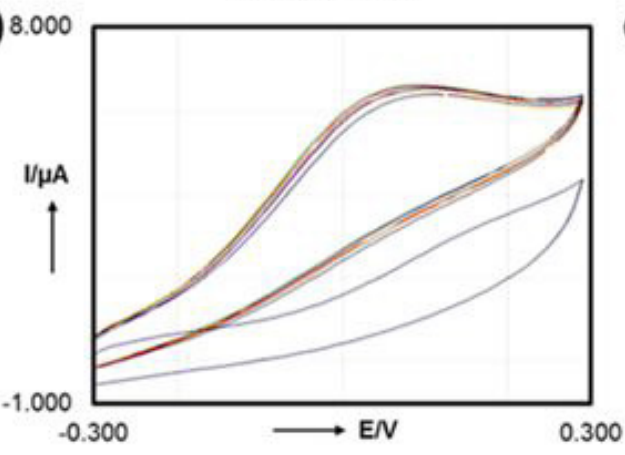

b)

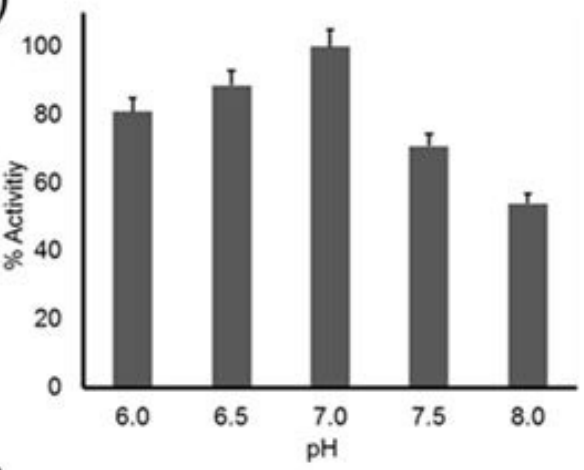

d)

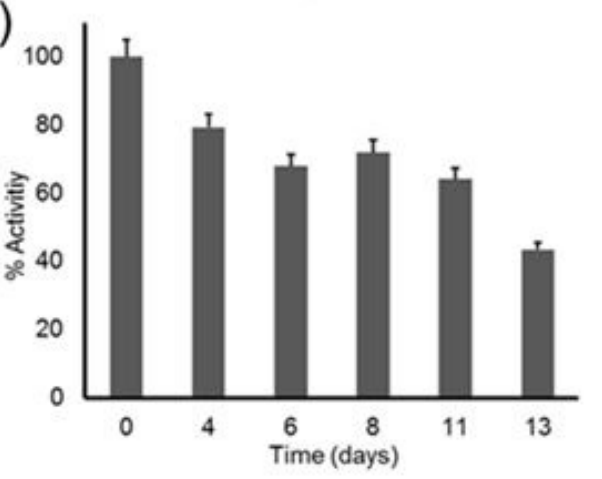

Figure 2. Optimization of working conditions, a) temperature, b) $\mathrm{pH}, \mathrm{c}$ ) the reproducibility and d) the storage performance of the tissue-biosensor.

biosensors is affected with the working $\mathrm{pH}$. To detect this effect, different buffer solutions at various $\mathrm{pH}(5.5,6,6.5,7,7.5,8)$ were prepared and used in the experiments. The results suggested that optimum $\mathrm{pH}$ was 7.0 as the highest biosensor response was obtained at this $\mathrm{pH}$ (Figure 2b). Because the result is compatible with the enzymes in their independent state, it is indicated that the immobilization process doesn't change the optimum $\mathrm{pH}$ value very much as the optimum pH of polyphenol oxidase is also 7.0 [19].

In order to investigate the working temperature, different biosensor systems were prepared at various assay temperatures between $15-40^{\circ} \mathrm{C}$ at $5^{\circ} \mathrm{C}$ increments. Low biosensor responses were received at between 20 and $25^{\circ} \mathrm{C}$ and at between $30-35^{\circ} \mathrm{C}$ it reached its maximum but on the further increase in the temperature a decrease was detected on the biosensor response (Figure 2a). The reason for that could be the temperatures above $35^{\circ} \mathrm{C}$ the gelatin starts to melt and the tissue gets loose. On the other hand, with the rise of the temperature, the increment of the diffusion rate of varieties of different chemicals causes the response to increase.

\section{Characterization of Analytical Parameters}

Linear dynamic range, stability, reproducibility, storage stability, substrate selectivity of the biosensor was investigated for characterization studies. Under optimized various operational parameters, the biosensor showed a linear response in the range of $10-100 \mu \mathrm{M}$. The limit of detection (LOD) was calculated as $3.2 \times 10^{46} \mathrm{~mol}$ $\mathrm{L}^{-1}(3.2 \mu \mathrm{M})(3$ per slope). Cyclic voltammograms and the standard graphs related to the CVs are shown in Figure 3.

The determination of the reproducibility of the biosensor was investigated at $50.0 \mu \mathrm{M}$ EP $(n=7)$. From the experiments, the average value $(\mathrm{AV})$, standard deviation (SD) and the coefficient of variation (CV \%) were found as $51.436 \pm$ 2.467 and $4.796 \%$ respectively suggesting high reproducibility of biosensor response.

The long term performance of the biosensor was evaluated intermittently over a period of 13 days by monitoring its response to EP (Figure 2d). The polyphenol oxidase enzyme is resistant to conditions out of its natural environment. Therefore, at the end of the 13th day, an activity 
a)

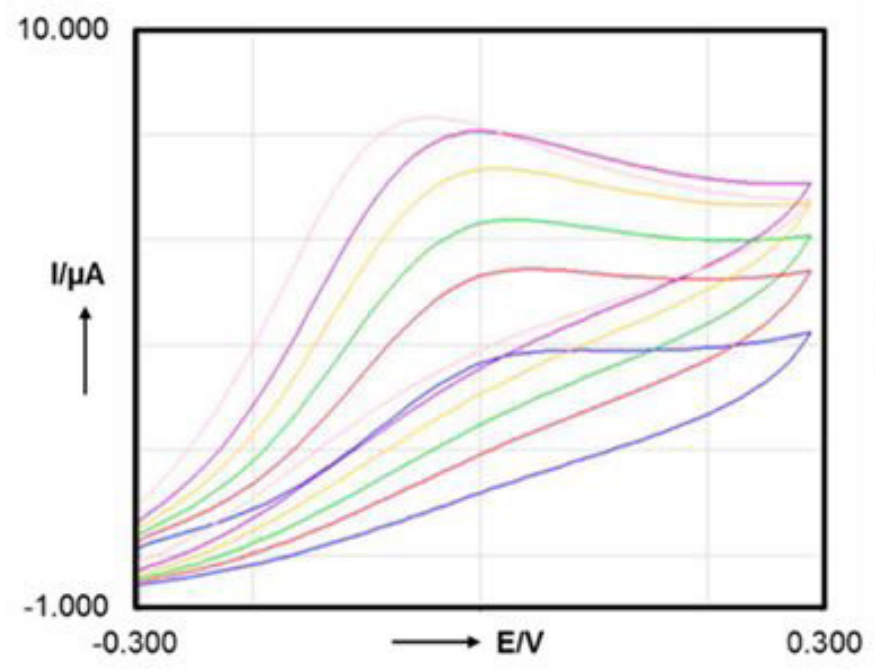

b)

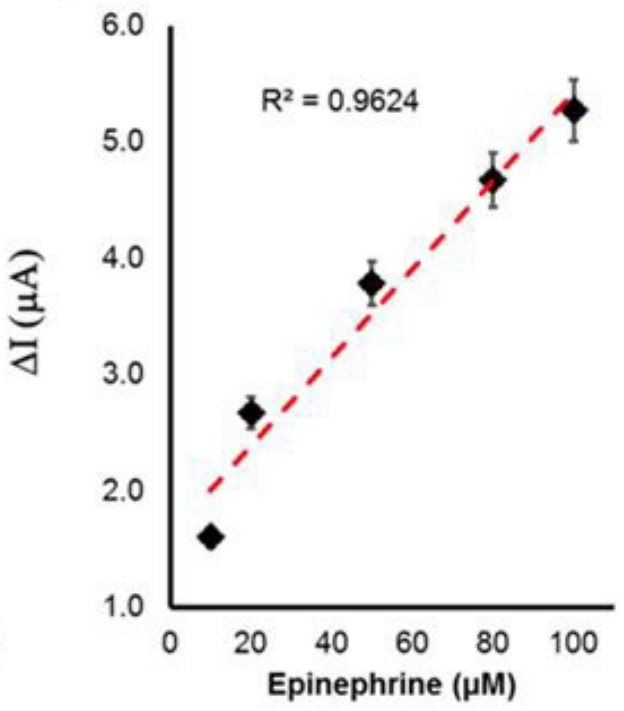

Figure 3. Sensitivity of the tissue-biosensor. (a) Cyclic voltammograms of different EP concentrations. Baseline (blue), 10 $\mu \mathrm{M}$ (red), $20 \mu \mathrm{M}$ (green), $50 \mu \mathrm{M}$ (yellow), $80 \mu \mathrm{M}$ (purple) and $100 \mu \mathrm{M}$ (pink). (b) Calibration curve obtain from 5 measurements. Experiments were carried out in $50 \mathrm{mM} \mathrm{PBS}$ buffer $(\mathrm{pH}: 7)$ at $30^{\circ} \mathrm{C}$, with $0.025 \mathrm{v} / \mathrm{s}$ scan rate.

less than $50 \%$ was observed. If the activity is accepted $100 \%$ for the first day then it could be concluded that there is not that much of a decrease in the biosensor response in two weeks. This decrease in the activity of the biosensor hence the variation in current could be attributed to the stability of the polyphenol oxidase and deformation of the bioactive layer by time.

In order to detect the substrate selectivity of the biosensor, the response was measured in the presence of L-ascorbic acid, glucose, catechol, tyrosine and phenol at $50 \mu \mathrm{M}$. These molecules were added in reaction mixture instead of EP. The experiments were carried out at $30^{\circ} \mathrm{C}$ between $-0,3 \vee \& 0.3 \vee$ potential range. The biosensor responses obtained for EP was accepted as $100 \%$ and compared to the biosensor obtained for the other substances. Results obtained from the experiments are given in Figure 4a. The results indicated that the biosensor responded to all substances because of inclusion of various metabolic process and enzymes of the tissue homogenate. It is a general knowledge that catechol and tyrosine are natural substrates of polyphenol oxidases. As a result of this, some responses were obtained for these compounds.
To investigate the interference effects of L-ascorbic acid, glucose, catechol, tyrosine and phenol on the biosensor response, $50 \mu \mathrm{M}$ of substrate was added to $50 \mu \mathrm{M}$ of EP and the effects of these substances in the presence of EP were investigated by the biosensor. Responses obtained for EP were accepted to be $100 \%$ and compared with the responses in the presence of other substances. From the experiments it can be concluded that the highest interference was obtained with tyrosine, catechol and phenol (Figure 4b).

\section{Real Sample Validation}

The biosensor was used for detection of EP concentration in pharmaceutical sample. For this purpose, the biosensor response for the samples were determined after they were diluted. EP concentrations of the same samples were also detected by spectrophotometric method to validate the results. Results obtained from two methods were shown in Table 1. The results suggested that tissue biosensors provided similar results with spectrophotometric method measurements as the values are close to the real values. Due to no necessity to any indicators, providing results in a short period of time, being easy to apply, being cheap and reproducible, 

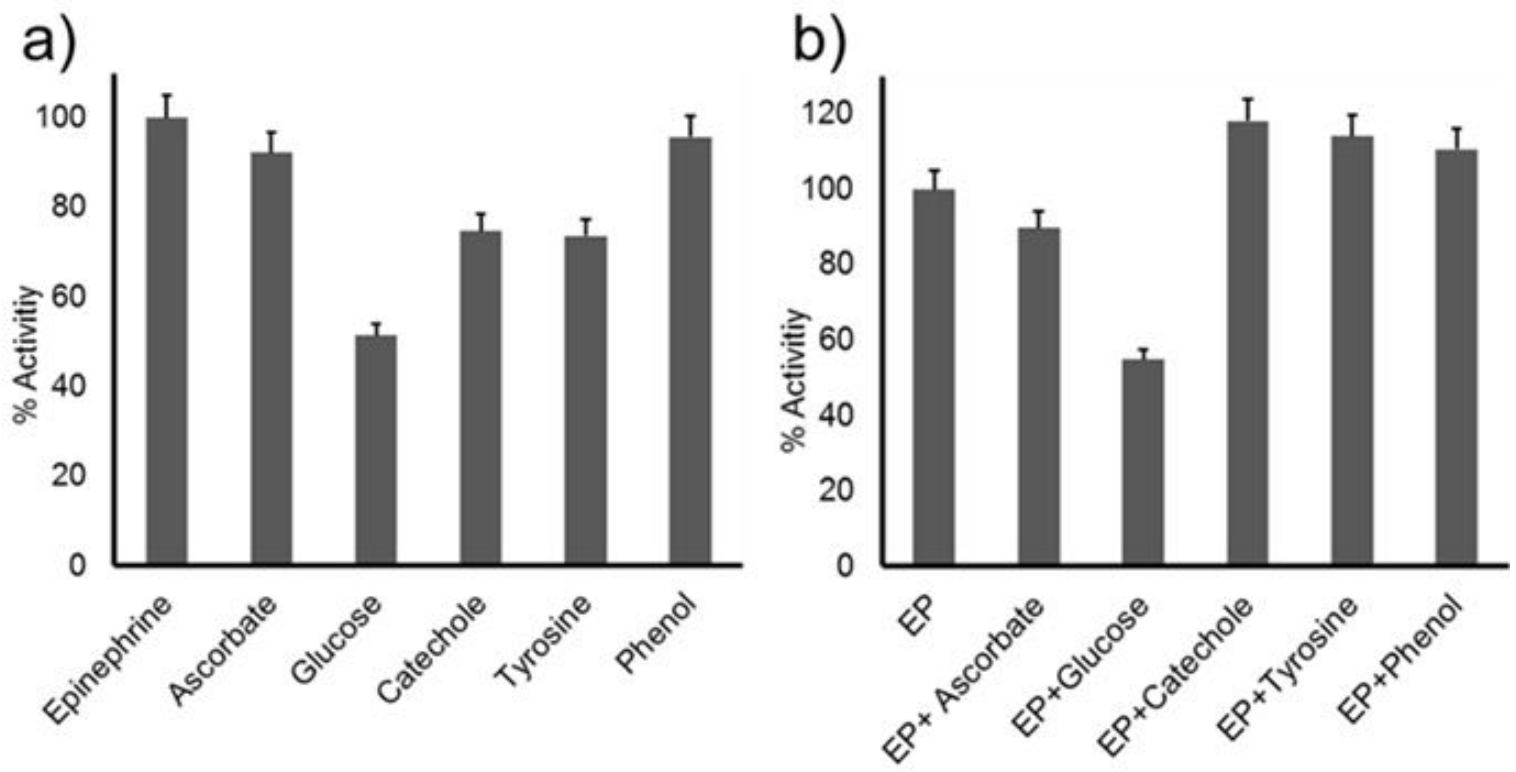

Figure 4. Selectivity (a) and interference (b) studies of the bisosensor.

Table 1. Real sample application.

\begin{tabular}{|c|c|c|c|c|}
\hline & $\begin{array}{l}\text { Reported Conc.* } \\
(\mathrm{mM})\end{array}$ & Spectrophotometry method (mM) & Biosensor (mM) & $\begin{array}{c}\text { Recovery } \\
(\%)\end{array}$ \\
\hline Galen Pharmaceuticals & 1.4 & 1.36 & 1.14 & 81.42 \\
\hline Biopharma Pharmaceutical & 2.8 & 2.73 & 2.56 & 91.42 \\
\hline
\end{tabular}

using biosensor is more advantageous over spectrophotometric methods.

Biosensor was used for detection of epinephrine concentration of adrenaline ampoules purchased from Biofarma Drug Company (Turkey) and Galen Drug Company (Turkey). For this purpose, samples were applied to biosensor after they were diluted. For corroboration of results, epinephrine concentrations of same ampoule samples were detected by using spectrophotometry method. *Epinephrine concentrations which were written on prospectus of drugs.

\section{CONCLUSION}

A myrtle tissue homogenate-based biosensor system for voltammetric detection of EP was developed. Biosensor was successfully applied for the determination of EP in a pharmaceutical sample with a wide linear range and low detection limit. It showed good stability in both acidic and basic media and reproducibility. Using the tissue homogenate as a biocomponent in biosensor construction with a simple immobilization procedure demonstrates a considerable economic advantage because of low cost, which is desirable in routine analysis. In this respect, the developed tissue homogenate-based biosensor has the potential to be a simple and inexpensive method for monitoring of EP in pharmaceuticals because of its simple preparation technique, the lack of extra purification steps required, and a rapid and easy operation. 


\section{References}

1. M. Campàs, R. Carpentier, R. Rouillon, Plant tissueand photosynthesis-based biosensors, Biotechnol. Adv., 26 (2008) 370-378.

2. J.S. Sidwell, G.A. Rechnitz, Progress and challenges for biosensors using plant tissue materials, Biosensors, 2 (1986) 221-233.

3. M. Lieberman, A. Marks, A. Peet, Marks' Basic Medical Biochemistry: A Clinical Approach (4 ed.) Philadelphia: Wolters Kluwer Health/Lippincott Williams \& Wilkins. p. 175. ISBN 97816083157272013.

4. M.A. Mohsin, B.D. Liu, X.L. Zhang, W.J. Yang, L.S Liu, X. Jiang, Cellular-membrane inspired surface modification of well aligned $\mathrm{ZnO}$ nanorods for chemosensing of epinephrine, RSC Adv., 7 (2017) 3012-3020.

5. P. Bougnères, C.L. Stunff, C. Pecqueur, E. Pinglier, P. Adnot, D.J. Ricquier, In vivo resistance of lipolysis to epinephrine. A new feature of childhood onset obesity, Clin. Invest., 99 (1997) 2568-2573.

6. P. Solich, C.K. Polydorou, M.A. Koupparis, C.E. Efstathiou, Automated flow-injection spectrophotometric determination of catecholamines (epinephrine and isoproterenol) in pharmaceutical formulations based on ferrous complex formation, J. Pharm. Biomed. Anal., 22 (2000) 781-789.

7. M.H. Sorouraddin, J.L. Manzoori, E. Kargarzadeh, A M.H. Shabani, Spectrophotometric determination of some catecholamine drugs using sodium bismuthate. J. Pharm. Biomed. Anal., 18 (1998) 877-881.

8. V. Carrera, E. Sabater, E. Vilanova, M.A. Sogorb, A simple and rapid HPLC-MS method for the simultaneous determination of epinephrine, norepinephrine, dopamine and 5-hydroxytryptamine: application to the secretion of bovine chromaffin cell cultures, J. Chromatogr. B., 847 (2007) 88-94.

9. M.A. Fotopoulou, P.C. Ioannou, Post-column terbium complexation and sensitized fluorescence detection for the determination of norepinephrine, epinephrine and dopamine using high-performance liquid chromatography, Anal. Chim. Acta. 462 (2002) 179185.
10. A. Kojo, E. Nalewajko, Determination of Epinephrine by Flow-Injection Analysis Using Luminol Hexacyanoferrate(III). Chemiluminescence Detection, Chem. Anal., (Warsaw), 49 (2004) 653.

11. W.K. Adeniyi, A.R. Wright, Novel fluorimetric assay of trace analysis of epinephrine in human serum, Spectrochim. Acta A., 74 (2009) 1001-1004.

12. P. Davletbaeva, M. Falkova, E. Safonova, L. Moskvin, A. Bulatov, Flow method based on cloud point extraction for fluorometric determination of epinephrine in human urine, Anal. Chim. Acta., 911 (2016) 69-74.

13. S. Wei, G. Song, J.M. Lin, Separation and determination of norepinephrine, epinephrine and isoprinaline enantiomers by capillary electrophoresis in pharmaceutical formulation and human serum. J. Chromatogr. A., 1098 (2005) 166-171.

14. F. Alpat, K. Özdemir, S. Kilinc, Voltammetric determination of epinephrine in pharmaceutical sample with a tyrosinase nanobiosensor, J. Sensors. 2016 Article ID 5653975, 9 pages.

15. S.F. Fabiana, M. Yamashita, L. Angnes, Epinephrine quantification in pharmaceutical formulations utilizing plant tissue biosensors Biosen. Bioelectr., 21 (2006) 2283-2289.

16. E. Akyilmaz, E. Dinckaya, A mushroom (Agaricus bisporus) tissue homogenate based alcohol oxidase electrode for alcohol determination in serum, Talanta, 53 (2000) 505-509.

17. S.M. Chen, K.T. Peng, The electrochemical properties of dopamine, epinephrine, norepinephrine, and their electrocatalytic reactions on Cobalt(II) hexacyanoferrate films, J. Electroanal. Chem., 547 (2003) 179-189.

18. H.S. Wang, D.Q. Huang, R. Liu, Study on the electrochemical behavior of epinephrine at a poly(3methylthiophene)-modified glassy carbon electrode, J. Electroanal. Chem., 570 (2004) 83-90.

19. M. Siddiq, K.D. Dolan, Characterization of polyphenol oxidase from blueberry (Vaccinium corymbosum L.), Food Chem., 218 (2017) 216-220. 